Kelly’s (1998) seminal exposition and refinement of mobilization theory has generally been well received within the field of British industrial relations since it appeared a decade ago. Yet there remains a paucity of empirical studies that attempt to relate the role of activists to specific workers' struggles (for some exceptions see Taylor and Bain, 2003; Heery and Conley, 2006; Simms, 2007). Moreover Fairbrother (2005) has recently mounted a fierce, although brief and undeveloped, critique of Kelly's alleged 'theoretically blinkered', 'one-dimensional' and 'vanguardist' conception of trade union leadership. Fairbrother complains that the starting point for a Kelly-type analysis is a leader-led dichotomy, rather than the nature of work and employment relations. He insists it is necessary to throw off the shackles of this 'poverty of leadership thesis' and return to more comprehensive forms of analysis such as the sociologically-inspired workplace case studies of Beynon (1973) and Batstone et al $(1977 ; 1978)$ that attempt to explore the conditions for various forms of workplace collective organisation, struggle, activism and 'leadership’ in terms of period, situation, sector and circumstance.

On one level Fairbrother's argument that questions of trade union leadership cannot be abstracted from the dynamics of social relations at work and its collective forms of union organisation is undoubtedly well founded. However, arguably a crucial feature of mobilization theory is the way it favours complex multi-factor explanations that seek to marry structural determination with deliberate agency. Thus while the centrality of agency in collective workplace mobilization, in particular the role of union leadership is reasserted, so is the question of the context and opportunity for collective mobilization: including, the structural conditions of labour and product markets, legal context, extent of management provocation, nature of workers' 
grievances, level of organisation and consciousness of workers, balance of power favourable to action, and the strength and traditions of solidarity.

However, Fairbrother’s explicit attempt to denigrate Kelly’s emphasis on the role of union activist leadership effectively blurs the distinction between activists and members and, by re-focusing on what is implied to be a more spontaneitist dynamic, ignores the way in which even though union activists do not, and cannot, create the underlying material conditions that can lead to conflict and mobilization, they can stimulate awareness of grievances and of the potential for collective action for redress; they can take the lead in proposing and initiating such action; and they can provide cohesion to discontent by generalizing from workers' immediate economic grievances to broader, even political, concerns. In this sense union leadership can be seen to be as important as any structural or institutional complexity in shaping the nature of collective action.

The attempt to counterpose Batstone et al's highly insightful accounts of social processes at the workplace $(1977 ; 1978)$ to 'vanguardist' mobilization theory is also completely misplaced. In fact Batstone provided one of the most detailed examinations of the processes through which shop steward 'leaders' seeking to shape a strategic workplace-wide perspective could foster collective organization and action. Efforts to prepare the members to act collectively, it was made clear, depended, in large part, on the continued educational role of the stewards' leadership in channelling and controlling rank-and-file discontent. This often involved the stewards in a protracted process of communication, 'vocabularies of motive', 'mobilization of bias' and 'systems of argument' to reinforce the collective interests of the group. Because of their influence 
stewards could, within limits, determine whether a stoppage occurred or which workers and what issues would be involved and along what lines a settlement would be reached. Previous studies such as Batstone et al's underline the fact that mobilization theory, however insightful, has not completely re-invented the wheel as regards the analysis of collective mobilization, even though mobilization theory provides a much more comprehensive analytical framework. But crucially mobilization theory, like Batstone’s studies, directs our attention towards the key role of activist leadership in highlighting grievances, 'framing' issues that identify a collective interest among workers, attributing blame to management, legitimising and encouraging mobilization, and responding to counter-mobilization by employers.

One significant limitation in Kelly’s approach that Fairbrother does not mention, but which also characterises his own work and is a common feature of much industrial relations literature generally, is the relative neglect of the whole topic of left-wing union leadership and its significance for collective mobilization. Yet there are some potentially interesting questions that could be posed, for example in unions like the RMT, PCS and FBU. How does a left-wing perspective influence union mobilization strategies? What evidence is there of the effectiveness of left-wing union leadership in terms of success/failure in gaining members' support, the extent and nature of collective action undertaken, the modifying of managerial behaviour, and the effect on union growth and strength? What are the conditions and contextual factors that enable left-wing activist leadership to be effective and the compliance or consent of followers to be granted? 
With such considerations in mind we can now turn to some case study research into the dynamics of union mobilization as displayed by the RMT in recent years, with the aim of examining both conditioning and influencing processes (structure and agency) on mobilization, and with specific reference to the relationship between workers’ combativity, collective organization, union leadership and left-wing activism.

\section{Case Study: The RMT}

The National Union of Rail Maritime Transport Workers (RMT) ${ }^{1}$ is one of the most militant and left-wing trade unions in Britain. One expression of this has been the way in which on London Underground and in different sections of the national railway network the union has explicitly rejected social partnership in favour of the repeated threat and use of strikes on issues such as pay, working conditions, pensions, and the effects of privatization. Thus on London Underground during 2000-7 the RMT has balloted for industrial action on no less than 30 occasions, engaging in strikes on no less than 11 different occasions (some of which have involved two or even three days of action). On the railway network during 2000-7 the RMT has balloted for industrial action on no less than 45 occasions, engaging in strike action on no less than 24

different occasions (again some of which have involved a number of days of action. ${ }^{2}$ Per thousand members, the RMT has probably organised more ballots for industrial action and more strike action than any other union over the last 10 years (including both ASLEF and TSSA, the other main railway and Tube unions). ${ }^{3}$ 
Strike ballots have frequently been used as a form of sabre-rattling designed to bolster the union's bargaining leverage, with no action resulting, although sometimes with significant concessions being obtained. But on occasions RMT strike threats have led to full-blown strike action, sometimes with devastatingly high-profile public effect. For example, a 48-hour strike by 2,300 Metronet infrastructure workers on London Underground in September 2007, to secure guarantees over jobs, conditions and pensions, wiped out the vast majority of the Tube network, inconvenienced 3 million people and caused an estimated $£ 100 \mathrm{~m}$ damage to London’s economy.

Such industrial militancy has been more than matched by political opposition to many contentious New Labour government policies, notably the government's refusal to countenance re-nationalisation of the railways and their subsequent partprivatization of London Underground, but also on many other issues. After reducing affiliation fees to the Labour Party for allegedly 'deserting its working class roots' and 'jumping into bed with its big business friends' (RMT News, July/August 2001), the RMT's decision to allow local union branches to affiliate to, and campaign for, non-Labour Party political organisations and candidates at local and parliamentary elections resulted in its expulsion in 2004 from the party it had helped to set up 100 years earlier. The historic break with the Labour Party has been emblematic of the militant trade unionism and left-wing radicalism embodied by the RMT.

Not surprisingly such a combative and left-wing union approach has been subject to vigorous critique. The London Evening Standard has argued it is the union's 'hard-left' militant leaders who should be held entirely responsible for the persistence of strikes on the Tube and railways: ${ }^{4}$ 'In an age when Scargillism is 
almost extinct, when most trade unions have become moderate bodies which recognise that they exist to serve their members, the RMT and its leaders represent a very sorry replay of Jurassic Park' ${ }^{5}$

Yet despite, or perhaps more accurately because of, such a militant approach, the RMT can legitimately claim several high-profile bargaining victories and advances on behalf of its members in recent years. For example, the threat and/or use of strike action have resulted in numerous above-inflation pay rises, as well as the 35hour working week on many sectors of the railway network and on London Underground (plus an annual 52-days leave entitlement on the latter). It has also achieved the reversal of attempts by Network Rail and other rail companies to end their final salary pension schemes for new starters, and contributed to bringing the private Metronet consortium contract back 'in-house', to be overseen by the publiclyrun Transport for London. Such an adversarial approach and the material benefits it has accrued has, in turn, contributed to a growth in union membership during the period 1999-2007 from 56,037 to 75,939 in 2007, representing a 37.3 per cent increase. ${ }^{6}$ Even though the absolute numbers are not large, it means the RMT is one of the fastest growing unions in Britain, which is no mean achievement in the context of merely stable or even declining membership for many others (Berlin, 2006; Gall, 2005a; 2006a).

Whilst industrial relations and trade unionism on the national railway network has been the subject of attention by some researchers in the past, (Ferner, 1985; Edwards, 1987; Hyman, Price and Terry, 1988; Pendleton, 1991a, 1991b, 1993, 1994, 1997; Freeman and Shaw, 2000; Murray, 2001) it has been largely ignored since 
privatization, whilst the London Underground has consistently remained almost completely unexplored territory (Darlington, 2001). This is remarkable considering the centrality of both industries to the day-to-day functioning of the British economy and society, the evident importance of railway/Tube stations and depots as major workplaces in their own right, the fact that both industries have experienced a relatively high level of strike action in recent years, and the combative and political form of trade unionism that the RMT has developed.

In attempting to fill the gap, this article builds on some preliminary studies (Darlington, 2001; 2002; 2006; 2007; 2008a; 2008b) to re-evaluate the relationship between union militancy and leadership, with specific focus on the role of left-wing RMT activists, within both the national railway and London Underground networks. 'Left-wing' is defined not only in terms of fixed affiliation to a political party but in the syndicalist-type sense of a consistently adversarial attitude towards management and a commitment to the wholesale redistribution of wealth and power in society. Drawing on the study of leadership provided by mobilization theory, the article explores the extent to which union leadership, notably by left-wing activists at every level of the union, has been an important contributory catalyst, symptom and beneficiary of workplace union militancy relative to other variables (such as the impact of privatization, managerial belligerence, and immediate grievances over pay and conditions, etc). Methods of data collection included extensive tape-recorded semi-structured interviews with 36 RMT informants at every level of the union (including shopfloor activists, workplace reps, branch officers, full-time national organisers and members of the Council of Executive), as well as 5 senior HR 
managers from different companies; analysis of documentary industrial relations and trade union material, and personal fieldwork observation at union meetings.

The article proceeds to provide a multi-dimensional set of explanations for the RMT's industrial and political militancy, examining in turn four interrelated factors: political economy, industrial relations, trade unionism, and left-wing activism. Finally, some conclusions are made and wider assessment is drawn with reference to current debates concerned with union revitalization.

\section{Political Economy}

The political economy context has been of importance not only in contributing to the broad underlying industrial discontent, but also in terms of the politicization of industrial relations and trade unionism on both the national railway network and London Underground. Privatization of the railways by the Conservatives took place in May 1996 despite network-wide strikes over the threat of job cuts and in defence of industry-wide agreements. It involved the separation of the running of trains from ownership of the track, and transformed a relatively well-functioning integrated service into a highly fragmented business. Apart from Railtrack (the privatised company that now owned the infrastructure of the railways and was responsible for operating the track, signalling and stations), there were 25 train operating companies, 3 rolling stock companies, 3 freight companies, 7 main infrastructure companies and literally hundreds of sub-contractors. 
Significantly, from an RMT perspective there was an acute sense of 'betrayal' with New Labour on the issue. In 1995, in the run-up to the special Labour conference which scrapped the party's historic Clause Four commitment to public ownership, Tony Blair and John Prescott had both nevertheless been keen to emphasise that a Labour government would see the restoration of a 'publicly owned and publicly accountable railway system’ (Murray, 2001: 16). But prior to the 1997 general election the party leadership abandoned its re-nationalization commitment and subsequently became even more wedded to the idea of private finance initiatives than its predecessors. Increasing disillusionment with New Labour inside the RMT has became manifest in a number of ways.

The biggest irony, and indeed failure, of privatization, it has been pointed out, is that far from reducing the cost of the railways to taxpayers, it has soared to unprecedented heights, with train operating companies simultaneously siphoning off billions of pounds in profits (Catalyst, 2004; 2005a; 2005b). The RMT's sense of outrage at the scale of this public subsidy of private finance has been reflected in its continued reference to 'rail profiteers' and 'fat cats' who have 'plundered the public purse', and the union has vigorously campaigned for re-nationalisation of the railways. The union has also been aggrieved at the perceived inherent tendency to undermine the safety culture of the national railway network brought about by privatization, with rail accidents at Southall (1997), Ladbroke Grove (1999), Hatfield (2000), Potters Bar (2002) and Lambrigg (2007). With the widely acknowledged failure of privatization to ensure adequate investment in infrastructure maintenance, Railtrack was taken into administration and replaced by Network Rail plc, a government-backed 'not-forprofit' company which in 2003 took back direct control of network maintenance from 
the private contractors (albeit still leaving renewal work in the hands of private companies). But the political dimension of health and safety has been underlined by the way in which corporate manslaughter charges were dropped over both the Hatfield and Potters Bar rail crashes, despite independent evidence that Balfour Beatty, Jarvis and Network Rail had failed to manage the inspection and maintenance of the track effectively. As a result, the RMT have argued than that on a privatized rail network 'profit comes before safety'.

In addition, the union has protested at the way New Labour have intervened directly in industrial relations within the rail industry by providing over $£ 23$ million of special compensation payments to train operating companies to indemnify them from revenue lost as a result of strike action. This has included strikes at Arriva Trains Northern (2002), South West Trains (2002) and Scotrail (2003). ${ }^{7}$ For the RMT this has been 'an astonishing abuse of public funds'. On top of the billions of pounds of subsidy already paid to the train operators, they have protested, it has effectively been government policy to subsidise industrial relations failure on behalf of employers by encouraging them provoke and prolong industrial disputes, thereby undermining good industrial relations (RMT News, July/August 2006).

The union's disenchantment with New Labour was considerably deepened by the part-privatization of the London Underground via the so-called Public Private Partnership (PPP). The government had intended the Tube PPP, the largest in the world and costing £455 million in legal and consulting fees to set up, to be in operation by 2000. But widespread public opposition, legal challenges and strike action by the RMT in 1998, 1999, 2001 and 2002, delayed the process until 2003. In 
order to circumnavigate the Tories' employment laws, the RMT's strike action was framed around the industrial relations 'effects' of privatization, with demands for guarantees concerning the terms and conditions of workers to be transferred to the private sector, but the stoppages were widely understood to be political action explicitly focused on a central plank of New Labour policy.

Like the national railway network, PPP resulted in London Underground's infrastructure being separated from the operation of train services. But in the case of the Tube the infrastructure was taken over by two private sector consortia (Metronet and Tube Lines) while train operations remained in the hands of the publicly-run London Underground Limited (LUL) under the political control of the Major of London, Ken Livingstone, and Transport for London (TfL). For the RMT, as for many independent observers (Wolmar, 2002; Sachdev, 2004), the result was a financial fiasco, with central government expenditure increasing more than twentyfold between 1997-2005 (RMT, 2007a). The financial disaster of PPP was highlighted in July 2007 when Metronet, responsible for maintaining and upgrading two-thirds of the Tube's infrastructure, was taken into administration after running up an estimated overspend of $£ 1.9$ billion. RMT strike action to secure guarantees over jobs, conditions and pensions from the bankrupt company's administrator, was accompanied by demands for the contract to be taken back under public control by TfL.

Disaffection with New Labour was compounded by the political about-turn of Ken Livingtone, who went from being an opponent of PPP to one of its supporters, and in turn became a harsh critic of the RMT. The union had provided fulsome 
support to Livingstone’s 2000 independent Greater London Assembly campaign for election to the newly created office of London's Major, with Livingstone having been excluded as the Labour Party's official candidate on the basis that he explicitly rejected part-privatization of the Tube. But following his spectacular election victory, Livingstone lost his legal fight to prevent PPP and promptly accepted he would now work with the private firms involved. He was shortly afterwards readmitted to the Labour Party and proceeded to distance himself from his erstwhile union supporters. In June 2004, just two weeks after winning re-election as mayor, Livingstone publicly denounced a strike over pay by LUL workers in dramatic fashion: 'Were I a member of the RMT, for the first time in my life I would cross a picket line'. ${ }^{8}$ One RMT rep commented: 'It's difficult to describe the anger within the RMT at Livingstone's call for scabs’. ${ }^{9}$ Moreover, despite TfL’s successful 2007 bid for the failed Metronet work to be brought 'in-house', albeit probably with some private sector involvement, Livingstone is proceeding with the unprecedented privatization of the Tube's East London Line, in the first stage of what the union fears could be the privatization of the whole operational side of the underground.

Meanwhile, as on the railways, the issue of safety on the London Underground has also been a fundamentally important undercurrent to the RMT's militant industrial and political stance, with number of Tube derailments (including Chancery Lane, Hammersmith, and Camden Town, 2003; White City, 2004; and Mile End/Bethnal Green, 2007) attributed to the perceived inherently unsafe nature of PPP. In addition, under the political inspiration of New Labour, LUL imposed new safety rule books in July 2007, effectively replacing regulations introduced after the King’s Cross fire in 1987 which laid down minimum fire standards and staffing levels. With the 
introduction of PPP contracts it was claimed such regulations were too prescriptive and placed a far too costly 'burden’ on the employer. By contrast, the new safety rules, estimated by the government to save business around $£ 36$ million over 10 years, have threatened a shift in emphasis from a regime of Inspections and Fire Certification to that of risk assessments and 'self compliance'. Under the campaign slogan of 'London Underground: I Do Mind Dying', the RMT have bitterly protested that the government's 'neo-conservative' belief in unregulated business acting responsibly is ill-founded; as a high-risk industry the railways would only be safe if the risks were controlled and tightly regulated (RMT, 2007b).

The refusal of New Labour to amend the Conservative governments' employment laws has been another issue of contention, with threatened strikes on both the railways and London Underground repeatedly subject to court injunctions by employers attempting to get the action called off. Gall (2006b) has estimated these sectors and the RMT have accounted for the largest overall number and percentage of court injunctions in industrial disputes during 1995-2005. In response, the union has been at the forefront of the campaign for a Trade Union Freedom Bill. More broadly the politicisation of industrial relations has been reflected in the RMT's antipathy to a whole raft of New Labour's economic, political and social policy, including the 'marketisation' of public services, embrace of globalisation and big business, and military intervention in Iraq.

\section{Industrial Relations}


The second contributory factor to the RMT's industrial and political militancy has been the industrial relations context, namely the nature of managerial action, workers' immediate grievances and the strategic industrial opportunities for union redress through collective forms of action. The transformation of the railway network from a single public entity into a myriad of private companies resulted in a fierce competitive battle, with antagonistic contractual relationships undermining co-operative working practices (Bagwell, 1996; Murray 2001; Strangleman, 2004; Wolmar 2005), and the drive to reduce costs (for example, on the infrastructure side by slashing the workforce substantially and sub-contracting labour) creating a high degree of job insecurity throughout the industry. Such insecurity within train operating companies (TOCs) has been further compounded by the short-term nature of franchises (with an average of only 6-7 years), which has hindered long-term planning. Ironically, given that at the end of the period a new company could win the franchise (for example, in July 2007 Arriva took over the Virgin Cross Country franchise and decided to restructure), such arrangements have inevitably sapped workers’ sense of allegiance and loyalty towards individual companies, with negative ramifications for the conduct of industrial relations.

Following privatization there was the accompanying break-up of the previous highly integrated national framework for collective bargaining, with each separate company now responsible for its own bargaining arrangements; there are currently over 100 different bargaining groups. Despite Network Rail taking maintenance work back in-house, there has remained a patchwork quilt of different pay rates and conditions introduced since privatisation for many engineering grades. At the same time in many TOCs the sometimes very acrimonious relationship between the RMT 
and ASLEF (representing exclusively train drivers) has been exacerbated by apparent classic 'divide-and-rule' management strategies aimed at stymieing the potential for united action by playing on the differences in bargaining representation and approach between the unions.

In some respects train drivers (mainly ASLEF, but also RMT) initially adapted fairly well to the arrival of company-level bargaining among TOCs, successfully exploiting advantageous tighter labour markets. In the late 1990s and early 2000s there was a shortage of drivers arising from the immediate post-privatization restructuring which cut-back many so-called 'non-essential staff'. When demand for rail travel actually increased, individual TOCs, faced with the prospect of future franchise reorganisation, felt little incentive to recruit and train new drivers, only to see them poached by another company. Instead they viewed bigger pay rises for their existing scarce drivers as a short-term solution, albeit accompanied by much more flexible working practices. But this sparked off a poaching war as other TOCs offered terms as good as their rivals, and in turn this encouraged a much broader layer of the companies' guards and station staff to attempt to maintain their relative pay levels rather than fall behind the drivers. As a result, thousands of RMT guards and station staff have been involved over recent years in a series of discontinuous strikes - for example with separate disputes on Virgin, South West Trains, Southern Trains, First North Western, Arriva Trains Northern, London Docklands Light Railway, and Scotrail - which in many cases have been successful. In this fashion the break-up of national bargaining in the rail industry has to some extent been matched, with the RMT mobilising its members in different individual companies behind a model 
minimum pay and conditions agreement (with a 35-hour basic working week emerging as the industry standard).

Nonetheless, there remain widespread differences in pay and conditions among RMT members within the same grade from one TOC to another, as well as often between existing staff and new starters within individual companies. Employers have often successfully pushed through against union resistance longer-term (often 23 year) pay settlements (with the consolidation of various shift and rest-day allowances into basic salaries), reductions in the level of overtime, more flexible rostering arrangements and more intensive working patterns. In response, the RMT has campaigned for an end to the fragmented industrial relations system with a return to national-level bargaining arrangements (Ewing, 2003).

On the London Underground PPP has also led to differential collective bargaining arrangements, and the erosion of the terms and conditions of employment, pensions and travel benefits of those transferred over to the private sector, which has contributed to industrial relations tensions. Moreover, even on the LUL publiclyowned operational side of the underground network, the fragmentation of management organisation, with line-based management structures, has had the effect of encouraging industrial relations disputes at local level (London Assembly. 2006: 7).

Managerial belligerence in both transport sectors in the wake of privatization and PPP has also helped to encourage the RMT's militant stance and undermined the possibilities for any alternative form of 'social partnership' arrangement as a means of protecting workers' interests. As the Financial Times acknowledged, on the railways 
the RMT could 'argue with some legitimacy that the rising tide of militancy is a direct response to a more aggressive employer agenda to boost productivity by tying pay deals to the reform of working practices in a bid to achieve efficiency savings'. ${ }^{10}$ Likewise on the Tube, the commercial imperatives at the heart of PPP have affected not just the infrastructure workers in the private sector but also the operational staff within the public sector. In February 2006 the RMT called on the LUL managing director to help break the cycle of disputes, pointing out: 'There is an overwhelming feeling among our Tube members that there is an urgent need to rein in managers who seem intent on continued confrontation'; 'it is the frustration of having to deal with daily attacks by managers who seem deliberately to be seeking confrontation that has resulted in our members seeking ballots for industrial action, and backing those ballots with substantial majorities for strike action'. ${ }^{11}$

Inevitably there has been some variation between different companies. For example, Brian Souter, millionaire chairman of Stagecoach, who took over the largest train operating franchise at South West Trains, has adopted a particularly aggressive management style towards the RMT, even sanctioning managers' strike-breaking in disputes in 2002 and 2006. Virgin Trains have also introduced a highly authoritarian style to enforce staff discipline, with HRM attempts to introduce a new young 'green' workforce, team working and a strong company loyalty ethos to seduce union organisation. By contrast, Northern Rail, First TransPennine Trains and other companies have generally been less confrontational. On London Underground 'Time to Talk' teambuilding sessions have been organised since 2005 on a line by line basis, with employees released from work to meet managers within a parallel machinery to union negotiation, with the aim of communicating over the heads of the union reps. 
Management regularly send out electronic bulletins to every depot, station and signal box. As one union rep explained: The key message is: 'We're a great team, we're all in it together. The unions just want friction and a fight over everything. But let's hold this all together'. Nonetheless a high proportion of industrial action ballots and strikes within both transport sectors appear to have been reactive and defensive protests against managerial attempts to drive through efficiency gains, worsen conditions of work and undermine collective union organisation. Issues related to discipline, and the dismissal of union reps who the RMT believe to have been 'victimised' for their union activities, have also been a common grievance precipitating action.

One highly significant contextual industrial relations factor that needs to be taken into account is the operational vulnerability of the railway and underground networks to strike action. Clearly the RMT's strategic position, industrially and within the economy and society more generally, has provided it with enormous potential bargaining power, not only to defend the pay and conditions of its members but also to act in a more offensive fashion. Even localised one-day strikes limited to individual companies can potentially bite hard; for example in March 2005 24-hour strikes by 170 guards in a dispute over the implementation of a 35-hour working week effectively brought Merseyrail services to a standstill. On a more dramatic scale the prospect of an industry-wide railway strike threatens to affect a complete shutdown of the network to commuters, as the RMT's planned 24-hour strikes over pensions in 2004 and 2006 vividly demonstrated. On the London Underground, the RMT Regional Council have successfully taken advantage of the union's distinct strategic position with a number of 24-hour combine-wide strike threats over the peakpassenger Christmas and New Year period (1998-9, 2000-1, 2004-5, 2005-6), as well 
as a threatened strike on the political symbolic London Assembly election day (June 2004), purposively designed to have maximum effect in order to put pressure on the employers to improve pay and conditions.

Unlike many public and private sectors elsewhere both industries are expanding in terms of investment and jobs, which has also encouraged union and confidence and bargaining leverage. In 2007 rail travel had reached its highest level for almost 50 years, and there is a projected increase in rail use of 30 per cent by 2015. ${ }^{12}$ Likewise the number of passengers travelling on the Tube has increased by over 25 per cent over the last 15 years. ${ }^{13}$ The London 'global city' factor is another important factor in the equation, with the capital now rivalling New York as the world's most important financial centre, and 18 per cent of the UK’s domestic product being generated from London. The capital is the origin or destination for 75 per cent of all rail journeys undertaken in Britain, underlining the extent to which the rail network is the key to London and the UK’s economy (London Assembly, 2007: 3). Apart from the current $£ 16$ billion Tube upgrade of stations, signals, tracks and trains, the newly restored St. Pancras International Station, the new London Overground network and projected Crossrail project (with an east-west link across the capital), there is the 2012 Olympic Games (which is likely to attract some 500,000 spectators a day). All of this has given enormous potential power to London's rail and Tube workers and the RMT more generally

\section{Trade Unionism}


Both the political economy and industrial relations contexts have been important in creating the underlying material conditions that have led to antagonism and strike activity on the railways and London Underground. They have contributed to workers' acquiring a sense of grievance/injustice, their attribution of blame for the sources of their discontent on employer/government, and the process of 'social identification' whereby they come to define their interests collectively in opposition to employers/government (Kelly, 1998). But the role of agency - namely the leadership role of union reps and activists - has also been a crucial resource necessary for collective action.

Despite the fact RMT organization on the railways and London Underground survived Thatcherism and the 1980s without suffering any crushing strike defeat, the imposition of privatization and PPP respectively in the 1990s and early 2000s impacted negatively not only in terms of the fragmentation of bargaining, flexibility offensive, and loss of jobs, but also in terms of the strength and vitality of union organization. On the railways in 1993, in the wake of two 24-hour network-wide allgrades British Rail (BR) strikes in protest at the threat posed by impending privatization, there was the ending of the union subscription check-off facility for the RMT (although not for ASLEF). This helped to plunge the union nationally into a financial crisis and, combined with the subsequent impact of privatization and widespread voluntary redundancies, resulted in the union's membership shrinking dramatically from more than 105,000 in 1992 to 55,000 by 1999. The ending of BR's national, regional and local-level collective bargaining arrangements scrapped a whole stratum of senior union reps (many of whom were on 100 per cent facility time) and led, initially at least, to a widespread sense of disorientation. Likewise on the 
London Underground, the 1992 imposition of a Company Plan, involving completely new contracts of employment, working arrangements and collective bargaining structures across the whole network, represented a serious defeat for union organisation with the loss of some 5,000 jobs between 1993-4 (Darlington, 2001: 10). The introduction of PPP which followed further undermined the strength of union organisation, notably with a marked decline in the level of membership on the privatized maintenance side.

Yet paradoxically, in the years that have followed there has been a relatively successful revitalization of RMT organization on both the railways and London Underground, with the refertilization of a new layer of union reps and activists. In part, this union renewal was encouraged by objective conditions, with an overall lowering of the average age of the workforces in both transport sectors, the exit of many fairly bureaucratised union reps and branch officers under the old structures, the emergence of a new generation of (in many cases younger) activists forced to adapt to the radically fragmented and transformed bargaining arrangements, and the different relationship between union reps and the membership encouraged by such broader changes. Also important has been the historical legacy of the formation of grassroots unofficial left-wing caucus groups determined to rebuild the strength of the union through the organization of militant collective struggle.

On the railways the Campaign for a Fighting and Democratic Union (CFDU), established in 1992, sought to revitalise overhaul the union's internal democratic structures and to directly challenge the moderate industrial and political leadership of the general secretary, Jimmy Knapp, for failing to mount sufficiently robust 
opposition to the impending privatization process. At its height in the mid-1990s the CFDU's loose national network meshed together up to 300 union officials and activists, members of different left-wing political parties and a much broader layer of independent non-party industrial militants and activists. It produced a regular newsletter, organised periodic national meetings in different parts of the country, and had the backing of almost 40 union branches and some Regional Councils, as well as among members on the Council of Executives. Individual supporters played a highly influential role within a series of national strikes by 'permanent-way' signal, telecoms and overhead line infrastructure workers over pay, conditions and hours in 1998, and a multi-company and industry-wide campaign of strikes by guards over their safety responsibilities during 1999-2003.

On the London Underground from the early 1990s there was the emergence of a similar, although less formally constituted, network of left-wing union activists to prominence. This involved a well-organised chain of influence stretching from union reps into the union branches, London Regional Council and Council of Executives. As on the railways, it embraced a range of members of political parties (notably in this case from the Socialist Labour Party led by Arthur Scargill) and non-party militants who were able to provide an influential leadership role, with an industrial strategy of militant opposition to management informed by broader left-wing political concerns (Darlington, 2001; 13).

One important fruit of the left's rising influence inside the RMT generally was the huge majority in support of Bob Crow's election as general secretary in 2002. Crow, who had been a supporter of the CDFU (as well as ex-member of the 
Communist Party and Socialist Labour Party), was elected on a platform of creating a 'fighting trade union' that would campaign to roll back privatization, and his victory was a manifestation of a new found sense of militant solidarity in the face of the perceived 'betrayals' of New Labour. Despite a sustained media red scare campaign subsequent electoral victories for the left at different levels of the union and Crow's overwhelming re-election in 2006 have further confirmed this trend.

As a consequence, although it no longer has any formally organised grouping as such, the RMT has a wide network of prominent left figures (from Bob Crow and full-time officers to Council of Executive members and lay union reps and activists on the ground) with fairly explicit left-wing political values, ideology, motivation and commitment, who from the early 2000s have been increasingly influential in shaping the union's rejection of social partnership in favour of the mobilisation of members as the means to win concessions. This has made it easier for an internal union culture of militant oppositionalism directed towards employers and New Labour, combined with robust collectivism and assertive style of leadership, to pervade the union, especially on London Underground.

Before looking in more detail at the specific role of left-wing political leadership inside the union, we can explore a number of important features of RMT organisation which to a large extent have been affected by such left-wing influence and which have contributed to the industrial and political militancy evident in recent years. The RMT is a relatively small, clearly defined and specialist (rather than general) 'industrial' union that organises across the transport sector, thereby embracing all-grades of employees (skilled and unskilled). The industrial and all- 
grades nature of the union provides the RMT with a clear identity, helping to encourage a high degree of attachment and loyalty to the union and there remains a relatively high level of union density on both the railways and Tube. The union has established a highly democratic/participatory form of structure and organization, which includes the election (rather than appointment) of all national and regional fulltime officers (who are subject to re-election after five years) and a directly elected lay-member Council of Executives (whose members must relinquish their post after a 3-year term of office). In addition central decision-making powers lie in the hands of the lay national grade conferences (for engineering, signalling, train crew and shunting, and station staff) and the Annual General Meeting (with delegates excluded from attending for more than a three-year successive period), thereby encouraging a high degree of devolved activist engagement.

Indeed in both transport sectors there are a sizeable layer of local RMT reps as well as health and safety reps who, by virtue of the operational significance of safety, also play an important union role. For example, on the London Underground there are well over 100 union reps and almost as many health and safety reps amongst a combine-wide RMT LU membership of about 6,100 members, excluding other RMT members who work for Metronet, Tube Lines and private cleaning companies. Such figures are much higher than recorded in many other industries by the WERS 2004 data (Kersley et al, 2006). Attendance at the RMT’s 14 Tube branches averages at 1520, although some (like Finsbury Park) attract 30-40. The London Regional Council, with delegates from every Tube branch, regularly attracts about 60-70 union reps and activists to its monthly meetings. On the railways there is also a relatively sizeable layer of union reps, although it varies between individual companies and stations. For 
example, at Bristol Temple Meads station which employs about 550 workers there are 48 RMT reps. The Bristol rail RMT branch, with a membership of about 1,000 members (spread across a wide geographical area), attracts a regular monthly attendance of about 25 reps and members, with up 50-60 on occasions.

Centralised union leadership has combined with the initiative of activists from below. On the one hand Crow has noticeably stamped his combative/oppositional leadership style towards management and New Labour on the union and helped to shape policy issues. On the other hand, the large milieu of assertive and combative lay workplace reps and activists have also played a crucial role in advocating and winning support for the mobilisation of union members in collective action. Such activists have been important in 'framing' issues by deciding what issues and initiatives to take up, framing them in antagonism to employers and government, and displaying leadership and organising skills. One expression of this has been the substantial ideological and propaganda effort consistently mounted at different levels of the union, involving numerous regular newsletters, leaflets, emails and text messages, which have operated in a context in which management has engaged in countermobilization to thwart effective union organisation and collective action.

The RMT’s strike strategy has also been an important contributory factor to the re-invigoration of union organization. The proportion of members voting in individual industrial action ballots, based on a fairly arbitrary selection of 15 different disputes across both transport sectors over recent years for which figures are available (Darlington, 2007), has been a highly impressive overall mean of 58 per cent and median of 64 per cent. The majority of ballots have returned overwhelming majorities 
in favour of action, an 82 per cent mean or 84.3 per cent median. Such relatively high levels of participation and support have bolstered the RMT's bargaining position and provided visible, material, measurable and high-profile examples to its members of the way in which the union can achieve its objectives for their benefit. In the process this has contributed to boosting the self-confidence of the members and their sense of collective power, and in turn encouraged union activism and recruitment. For example, the LUL RMT Engineering branch experienced an influx of dozens of new members as a result of the combative stance adopted in the 2007 Metronet strike.

Such a strike mobilisation strategy has been accompanied by the RMT's comprehensive application of a distinct version of the 'union organizing' model. This has involved a national campaign, coordinated by a special organising unit set up in 2002, to recruit new members, not only amongst the 'core' railway and Tube workforce of drivers, guards, signallers, infrastructure workers and station staff, but also amongst groups for whom the union had become marginalised by privatisation, such as cleaners, catering and security staff. In the process it has won new recognition agreements (for example, with infrastructure companies McGinley, Renown and Grantrail, station catering company Select Service Partners, and security firms Securitas and Chubb). But the union's strategy has also involved a prioritisation of the development and creation of active, self-sufficient and sustainable union reps able to provide effective workplace representation, including the establishment of a new training centre in Doncaster. Likewise a national database of some 1,200 activists, who are not (one of the 2,000) union reps but nonetheless willing to be involved in recruitment has been compiled and utilised. As a result of such organizing efforts the union has not only had success in recruiting new members, but also in strengthening 
workplace union organisation and energizing reps and activists in a number of areas (for example, Eurostar).

\section{Left-Wing Activism}

As we have seen, one of the legacies of a highly politicized industrial environment, and of previous internal battles over strategic direction within the union, is that the RMT has a wide network of left-wing activists within its ranks. Such activists have exercised a significant industrial and political influence within both the railway and London Underground networks, albeit to a greater extent in the (more strike-prone) latter than the former. Thus on the Tube's RMT Regional Council there has been a combination of what one union activist has termed a 'political left' and a 'syndicalist left'. On the one hand, a number of hard-left political organizations have representation of between 2-6 members each. There are also a number of delegates who are no longer a formal member of a political party, but used to be a member of one or other group in the past and remain highly political in their overall approach. On the other hand the 'syndicalist left' element is composed of a broad variety of industrial militants, most of whom are, like their party counterparts, implicitly anticapitalist in outlook, adopt a consistently adversarial approach to management, play a key role in leading disputes and necessarily take up political arguments in the process of mobilization.

While formal left-wing political party representation is much less evident on the national railway network, there are some very prominent left-wing influenced 
activists amongst the different grades and within individual companies and most of the RMT's full-time organizers and lay members of the Council of Executives are likewise noticeably on the left on industrial and political issues. Many of these activists are motivated not just by a struggle against workplace injustice or industrial issues, but also by the search for social justice outside the workplace, giving issues a political dimension, invariably with an anti-New Labour edge. In other words then, if privatization and PPP and its ramifications have contributed to the politicization of industrial relations and trade unionism, both transport sectors have collected together a layer of left-wing activists who have an 'axe to grind' with a more or less politically informed agenda. Apart from their impact on the nature and extent of strike mobilization within the union (Darlington, 2008a), evidence of the influence of such left-wing activism on a much wider layer of members can be explored in relation to the Iraq war and the break with the Labour Party.

From the outset the RMT opposed the government's military intervention in Iraq and officially supported the Stop the War Coalition movement of opposition (Murray and German, 2005). Across the country individual regions and branches, including the union's AGM, endorsed this stance. Likewise the Regional Council on London Underground, with a policy of calling for the withdrawal of British troops, mobilized dozens of members for the mammoth 15 February 2003 anti-war demonstration. Immediately after the 7 July 2005 London bombings the union made it clear the bombings were a criminal act and sent sympathies and solidarity to the families and friends who had lost loved ones. But Bob Crow also explained: 'There is no getting away from the fact that the war Tony Blair led us into in Iraq was a criminal act too. That war was based on a pack of lies and it has now resulted in the 
very escalation of violence that we, as part of the anti-war movement, warned of' ${ }^{14}$ The union's left-influenced Tube Regional Council emphasized the way in which workplace safety was closely intertwined with not just government economic policies but also with the military adventures it was pursuing abroad. First, it argued that whilst the union was constantly being told by government that privatization and PPP were necessary for the much-needed investment in public transport, health and education, there appeared to be a bottomless pit in the public purse to fund wars. Second, it drew attention to the way in which the private companies who were making huge profits from the railway and London Underground networks, through the intensification of work effort and deterioration of safety protection, were the same companies who were profiting from the lucrative contracts awarded to them by the American and British governments in 'reconstructing' Iraq. July 2005, it argued, made those links starker than ever before (RMT, 2007b).

As a consequence, in the immediate hours after the 21 July 2005 attempted repeat bombings, leading Tube RMT reps refused to encourage their members to work normally as requested to do so by Tony Blair (via the Cabinet Office Briefing Rooms, COBRA) and London Underground. ${ }^{15}$ One union rep recalled:

There was there was an attempt to get the unions on board, to agree to send out a political message that it was nothing to do with Iraq, it's just loony Islamic fundamentalists and we won't give in to them... We didn't accept it. Everyone knew it was the Iraq war that caused it. We told them ‘we don’t trust you, we don’t trust management, and we certainly don’t trust No. 10 . 
.... a number of our members refused to work...[they] wouldn’t go out and drive the trains or open up stations or continue any back work until there was an absolute guarantee that the entire combine was checked, inspected, security cleared.

After the Tube network returned to normal working, the Regional Council campaigned for the re-introduction of guards on trains, greater station staffing numbers, and better communications, and argued that in the event of another confirmed attack the whole system should be closed in a coordinated manner to allow for safety and security checks prior to re-opening. They also reasserted the need to campaign on a wider social basis as an affiliate to the Stop the War Coalition to deal with the 'root cause of the conflict' - US/UK foreign policy. Although the proposed practical measures were framed around the issue of safety, the RMT's stance was clearly informed by an explicit left-wing political set of assumptions related to opposition to the war in Iraq.

The influence of the left inside the RMT was most decisively demonstrated in the crucial role it played in encouraging the union, after a number of years of internal debate, to break its historic link with the Labour Party, on the basis that New Labour had destroyed the party's core principles. Historically the RMT (and it predecessor union, the NUR) leadership had always been proud of the union's strong links with Labour at all levels. Under Knapp’s helm as general secretary, the union had established particularly close links with the shadow Labour cabinet and from 1997 had high expectations of the incoming New Labour administration. In addition, a significant number of union activists were Labour councillors and at the grassroots the union boasted the highest density of Labour Party membership of any trade union, proportionate to its size, with 3,000 members (Tucker, 2002; Berlin, 2006: 133). 
Though some leading members, many of whom were associated with the 1990s CFDU grouping, had left to join the Socialist Labour Party, formed after Labour's rejection of Clause Four, there was little grassroots support for the idea of disaffiliation. But the process of dissolution of the historic link came by a series of incremental and increasingly acrimonious stages of confrontation with the Knapp leadership, as growing section of the union, faced with New Labour's neo-liberal policies, became unhappy with the leadership’s loyalist approach to New Labour.

The election of Bob Crow emboldened the left elements inside the union, who decided to throw down the gauntlet over the question of the use of the RMT's political fund, rather than on the explicit and contested demand for a full-blown separation from Labour. But in arguing that the political fund should be used as the members thought best in each circumstance - to back Labour Party candidates where they were supportive of RMT policies and to back other independent political candidates where they were not - the implicit political justification for a break with Labour was effectively expressed with increasing vigour and support at successive union AGMs. The scale of the revolt was underlined when, following a refusal to accept the RMT's loyalty pledges of re-nationalisation of the railways, scrapping of part-privatisation of London Underground, and repeal of anti-union legislation, the union progressively reduced the number of its members affiliated to the Labour Party and cutback its affiliation fees. In 2003 the union moved even further along the path of confrontation with New Labour when it voted in favour of allowing individual branches and regions to affiliate to, and campaign for, other non-Labour Party political organisations and candidates at local and parliamentary elections. 
A number of RMT branches, no longer able to stomach giving local affiliations to constituency Labour Parties, began to support independent political campaigning. For example in the Greater London Assembly elections of 2000 ten RMT London Underground workers, led by Pat Sikorski (newly elected as Assistant General Secretary), ran as candidates as part of the Regional Council's Campaign Against Tube Privatisation, in the process gaining 17,000 votes. This was followed by the RMT Council of Executive's decision to allow five Scottish branches and its Scottish Regional Council to affiliate to the Scottish Socialist Party, after which Labour's deputy general secretary, Chris Lennie, wrote to the union saying it 'has placed itself outside the constitution of this Party'. Following a decision to refer the matter to the Labour Party's national executive committee with a recommendation that the RMT 'be treated as disaffiliated from this Party forthwith' (Labour Research, February 2004), a RMT special general meeting in February 2004 refused to be 'bullied' and decided to reaffirm its policy of supporting other political organisations that reflected union policies (by a 42-8 vote). As a result the union was expelled, by which time there were estimated to be only 300 members of the union left in the Labour Party (Berlin, 2006: 159).

In January 2006 the RMT, following an initiative from the union's left elements, hosted a conference open to trade activists from others unions to discuss ‘The Crisis in Working Class Political Representation’ which delivered a damning indictment of Labour and scorned the possibility of resurrecting it as a workers' party. Even though the RMT leadership have refused to commit the union to launching a new political party - in fact paradoxically it has subsequently reinvigorated its RMT parliamentary Labour Party group headed by left-wing MP John McDonnell - the 
left's activities have contributed to opening up arguments about a potential political realignment around a new left-wing party backed by the unions. In the meantime the union has taken the initiative to sponsor the launch of a National Shop Stewards' Network, viewed as the first step to revitalize the grassroots of the trade unions and build a fighting union movement generally in Britain.

Finally, it is possible to discern the left's influence within the RMT in the extent to which a form of political trade unionism has become embedded within the organisation's activities generally, involving an explicit opposition to the neo-liberal agenda that engulfs established political parties. Thus the union has taken some important steps to broaden the agenda of trade unionism by making common cause with a range of social movements, including the Stop the War Coalition, Unite Against Fascism and anti-capitalist European and World Social Forums All these initiatives have been well supported by left activists in different Regions and branches of the union, and mark a limited but notable attempt to reorient the union as a social actor towards a broader political agenda.

\section{Some Conclusions}

In attempting to explain the reasons for the RMT's industrial and political militancy on the railways and London Underground there have clearly been some important objective features, including: the politicization of industrial relations and trade unionism as a consequence of privatization/PPP; organisational restructuring and management belligerency; buoyant markets and increased passenger volumes; the 
homogeneity of large manual workforces with a relatively high union membership; and the immediate impact that strike action can potentially have on operational services and the public. All of these factors have contributed to creating a favourable environment for workers to engage in militant union activity compared with the more quiescent labour and union response in other industries in recent years.

But while such environmental features may have created a more or less favourable context, they have not, in themselves, necessarily generated a sense of injustice or collective identity. Hence the importance of the role of union activists at every level of the RMT, and in particular left-wing activists, in providing leadership in the mobilization of collective discontent and workplace strike activity, as well as in influencing the political break with New Labour. The efficacy of mobilization theory as a tool of analysis of such social processes deserves due recognition, despite Fairbrother's (2005) critique. Conversely, while the media-propagated 'agitator theory' of strikes exaggerates and presents a distorted picture, the fact that trade union militants and/or left-wing activists do not in any sense cause the underlying material conditions that lead to antagonism and strike activity should not blind us to the way that their activity and leadership is clearly an important variable (amongst other factors) to an understanding of the dynamics of mobilization (Darlington, 2006).

Such a structure-agency dynamic can also help to explain the relatively higher level of union militancy on the London Underground compared to the railways. The Tube network is situated within a much more compact geographical area with a closer social network; there is a much higher concentration of workers both in absolute terms and located within many large depots/stations; there is much less employer and 
collective bargaining fragmentation; there is a greater degree of publicly-owned influence and political pressure susceptibility; and there is the heightened potential impact of strike action within the capital, given the density of passengers, link to every mainline station and effect on the City of London and Heathrow airport. However, also of central importance is the higher density of union membership, greater strategic coordinating role of the Regional Council, and more deeply implanted and influential left-wing activist traditions.

Beyond such considerations the case study evidence also sheds some light on current debates concerned with union revitalization. According to a number of studies (for example, Jowell et al, 1984-1996; Charlwood, 2003; Bryson, 2003), one of the principal reasons why British workers generally are not joining unions in greater numbers is that they are often viewed as simply not being effective enough. Yet if the experience of the RMT's significant growth in union membership in recent years is anything to go by, it would seem that what attracts workers to join the union is precisely its apparent ability to deliver in terms of obtaining real and demonstrable material improvements in pay and conditions. Nonetheless, in order to be in a position to extract such concessions from employers, the RMT has had to adopt a combative stance, often involving the collective mobilization of members and the threat and use of strike action.

However, as other commentators (Behrens et al, 2004; Kelly, 2005) have pointed out, much of the literature on the topic of union revitalization has equated it simply with membership growth. But the activities of the RMT demonstrate that revitalization can occur on dimensions other than membership. Thus, it is possible to 
see evidence of variation in outcomes if we adopt Behrens et al's multi-dimensional conceptualization of union revitalization that moves beyond union membership and density to embrace economic bargaining power (to achieve pay and benefit improvements), political leverage (to influence the policy-making process), and institutional vitality (capacity to recognize and respond to changes in the environment). Likewise Stirling (2005) has argued we need to define union renewal in ways which take into account not only recruitment and growing membership, but also features such as increased success in collective bargaining, stronger workplace organization, greater militancy, extent of union democracy, the role of workplace activists as leaders and so on. In other words, union revitalization and renewal cannot be measured along a single dimension, there is multi-dimensionality. Arguably on the basis of such a range of measures, the RMT has scored fairly well. Their experience belies the pessimistic claims of those (Coats, 2005) who have claimed the unions, like the biblical Lazarus, somehow need a miracle to come back to life.

Meanwhile Cohen (2006) has recently drawn attention to the central role of lay union activists to maintaining union organization and the process of union renewal. The case study evidence presented here appears to underline such an assessment. Certainly, compared with many other industries where there are often workplaces with a union presence but no active union reps to provide effective representation, the existence of a committed activist milieu inside the RMT, able to influence and lead worker mobilization, appears to be crucially important feature of union organization. But while Gall (2005b) has reminded us that the body of left activists is considerably smaller today than it previously was, there is clearly a new generation of RMT members who have been politically radicalized over the last few years within the 
national railway and London Underground sectors. Such a network of left activists, while no doubt somewhat less politically and organizationally cohesive than in many other industries where the Communist Party previously had a base, nonetheless appear to have exercised as much ability to influence a wide layer of workers and lead struggles. Yet the favourable industrial context and politicization of industrial relations which has contributed to sustaining such a development limits the extent of case study generalization that can be made.

Ironically, in advocating the central role of lay union activists as 'ramparts of resistance', Cohen (2006) has dismissed the activities of left-wing political groups, criticising their alleged attempt to pull workers over to extraneous broader political agendas rather than concentrating on the prosaic terrain of workplace resistance. In fact, the case study evidence suggests that left-wing activists in the RMT have been crucial to the task of building union organization and collective industrial and political mobilization. Far from such activists 'substitu[ting] political idealism for strategic, conscious building of rank-and-file organisation and resistance' (p. 182), they have enjoyed considerable success in taking up and articulating members' grievances and sense of injustice, suggesting means of redress, organizing collective forms of union organisation and action, and generalizing politically from such endeavours.

\section{Notes}

${ }^{1}$ The RMT was established in 1990 as a result of an amalgamation of the National Union of Railwaymen (NUR) and National Union of Seamen (NUS).

${ }^{2}$ Figures have been compiled from a variety of published and unpublished sources 
emanating from the Office for National Statistics, employers, the RMT, newspaper reports and elsewhere. See Darlington (2007).

${ }^{3}$ Associated Society of Locomotive Engineers and Firemen (ASLEF) and Transport Salaried Staffs’' Association (TSSA).

${ }^{4}$ Editorial, 'Militants Behind Action Bringing Commuter Misery', Evening Standard, 22 June, 2004.

${ }^{5}$ Editorial, 'Hardliners on the RMT’, Evening Standard, 16 May, 2001.

${ }^{6}$ Figures supplied by the RMT.

${ }^{7}$ John McDonnell, House of Commons Hansard Debates for 28 February 2006, London: The United Kingdom Parliament; Transport Select Committee, 19 July 2006.

${ }^{8}$ R. Lydall, 'Ken: Cross Picket Lines, Evening Standard, 26 July 2004; K. Maguire, 'Livingstone in “Scab” Row’, Guardian, 26 June 2004.

9 ‘We Will Not Cross a Picket Line, Ken’, Socialist Worker, 3 July 2004.

${ }^{10}$ D. Turner, ‘Tough Talk all the Rage for Unions’ New Faces’, Financial Times, 5 August 2003.

${ }^{11}$ Letter from Bob Crow to LU Managing Director Tim O’Toole, RMT 14 February, 2006.

12 Network Rail (2007) Business Plan 2007; Transport for London (2006) A Rail Strategy for London's Future.

${ }^{13}$ Transport for London, Annual Report and Statement of Accounts 2006/07, p. 20.

${ }^{14}$ B. Crow, 'It's the War Stupid', Across the Tracks, July 2005.

${ }^{15}$ Summary of Proceedings of a Special Meeting of LU Health and Safety Forum, 8 July 2005; Notes of LU Health and Safety Forum, 13 July 2005; Summary of Proceedings of London Underground Ad Hoc Health and Safety Forums held on 21 and 22 July 2005. 